VLADIMIR JEREBIĆ, Ph.D. Candidate ${ }^{1}$

(Corresponding author)

E-mail: vladimir.jerebic1@optinet.hr

STANISLAV PAVLIN, Ph.D. ${ }^{1}$

E-mail: stanislav.pavlin@fpz.hr

1 University of Zagreb,

Faculty of Transport and Traffic Sciences

Vukelićeva 4, 10000 Zagreb, Croatia
Transport Logistics

Preliminary Communication

Submitted: 6 Feb. 2017

Accepted: 5 Feb. 2018

\title{
GLOBAL ECONOMY CRISIS AND ITS IMPACT ON OPERATIONAL CONTAINER CARRIER'S STRATEGY
}

\begin{abstract}
The shipping market is an economic derivative of global production and trade, being precariously subject of their cyclic changes, depressions and expansions. This paper analyses the condition of global container shipping market, caused by long-lasting economic and financial crisis that begun in 2008, but is still much visible within the container industry, particularly through overcapacity and low freight rates. It also deals with major changes of maritime container carrier's management strategies, development and application of advanced transportation, technological, technical, economical, organizational and commercial measures in order to adapt and cope with new business environment. Finally, an attempt is made to forecast the market, potential difficulties and to propose problem-solving measures.
\end{abstract}

\section{KEY WORDS}

container shipping; economy crisis impact; operational strategy changes; consolidation; market forecasts;

\section{INTRODUCTION}

Container shipping is an integral part of the globalization process as well as an important factor of sustained economic development. During the year 2016, there were 10.3 billion tons shipped out by sea, which is $80 \%$ of the complete world's trade [1]. During the same year, the share of goods carried by containers reached 1.72 billion tons. World was never better connected and dependent on the sea trade as today. Being a derivative of the World's economy, container shipping is vulnerable to external factors, such as volume of international trade, political situation, financial trends, technological development and international and national legislation. All of those factors directly or indirectly influence the demand for transportation. Financial crisis, commenced in 2008 , rapidly projected from financial into the industrial sector and as a result international trade dropped by $14.4 \%$ for the first time since 1982 . World GDP plunged by $2.2 \%$ dragging down the transportation demand and collapsing the freight rates. As a result, dynamics and mechanism within shipping industry were gravely disrupted creating huge overcapacity and causing freight rates to drop to their historical minimums [1].

Under such business environment, with their very existence on the market being threatened, companies had to adapt and develop effective strategies and measures to cope with new, changed circumstances.

Taking all above into consideration, the aim is to review the shift of strategies and present the measures taken so far to consolidate the container shipping, as well as to give a forecast of the future market condition.

\section{ROAD TO CRISIS}

A favourable economic and technological situation at the end of $20^{\text {th }}$ century has greatly accelerated the containerization and container shipping. The newly established global production system with strategically worldwide spread resources and cheap workforce, demanded an affordable and reliable logistic chain. Containerization, as an inter-modal transport of high efficiency, reliability and flexibility has been a logical and cost-effective answer to demands of modern production and trade functions. The technological developments in shipbuilding, port terminals and port equipment, as well as political integrations in Europe, world trade agreements, tariff regulations, easier access to financial loans as direct result of communications and IT support improvements were the fundamental factors of unhindered development of international economy, trade and, naturally, container shipping.

Increased volume of international trade and steady growth of GDP for the period from 1990 onwards, have expanded the containerized traffic from 28.7 million TEU (Twenty-foot Equivalent Unit is the capacity unit in inter-modal container shipping, related to standard ISO container with dimensions: $6.1 \mathrm{~m} \times 2.44 \mathrm{~m} \times 2.59 \mathrm{~m}$ and volume of $38.5 \mathrm{~m}^{3}$ ) to 152 million TEU [1]. Such steep increase of traffic caused discrepancy of supply and demand on the container shipping market, on the demand side. Due to easy loan access and high 
return of investments the operators started to order new tonnage. These new building, thanks to technological advancements got bigger and more efficient in both cargo-carrying capacity and fuel economy, further reducing the expenses incurred through its normal business operations. These expenses are called operating expenses and are often abbreviated as OPEX. However, the usual new building delivery time is two to three years, so the tonnage ordered during the expansion years was scheduled for delivery only after the onset of 2008 crisis or even later. By the beginning of 2009 , the total number of container ships reached 4,693 with cumulative cargo capacity of 12.1 million TEU [1]. Table 1 shows the growth rate of demand and supply and its disproportion upon the beginning of the crisis.

It is clearly visible from Table 1 that demand for transportation capacity has been reduced from double digits growth up to 2007 , to a single digit or even went to negative values during the peak of the economic crisis in 2009. At the same time shipyards continued to deliver new tonnage. The result was an overcapacity and drop of freight rates and even today, we can still feel its consequences.

Container shipping is mirroring the cyclic nature of the economy and finance. In general, crisis begins with stagnation of production and trade, followed by industrial recession and finally depression. Such order of crisis onset may provide indications and warnings for shipping companies to commence actions and procedures to mitigate the effects. However, the 2008 crisis began in the financial sector and without clear insight in the financial market and macroeconomic indications of trade imbalances, the trend of ordering new tonnage just kept going on and on. There are three main drivers to trade imbalances: low labour cost, particularly in the basic and consumer industry, public debt and impairment loss of capital assets and real estate and direct financial investments in low production cost regions as well as transfer of knowledge and technology [2].

As a direct result of crisis of financial crash and production and trade decline, the overcapacity and short demand caused radical fall of the freight rates that led into insolvencies, laying up the vessels, losses and in some cases bankruptcies.

\section{CRISIS IMPACT ON CONTAINER SHIPPING}

The connection between financial and insurance houses and shipping carriers is a close-knit symbiosis. Shipping is a very capital-intensive industry due to high value of the ships and such relations are natural and essential. However, a long-standing practice of passive investment and insurance, due to extraordinary return of investment has been replaced by a more active role and even direct operational control in some cases. The world economic crisis started in the financial sector in 2007 and culminated in autumn 2008 ended up in the collapse of production, investment and international trade. Such a dramatic recession has caused steep drop of demand for transportation, spreading the crisis into shipping.

\subsection{Consequences}

The consequences to container shipping, directly emerged from the onset of crisis, could be classified into several groups [3];

- Overcapacity of cargo space,

- Freight rates downfall,

Table 1 - Demand and supply growth rate for container space (in \%) [1]

\begin{tabular}{||l|r|c|c|c|c|c|c|c|c|c|c|c||}
\hline \hline Year & 2004 & 2005 & 2006 & 2007 & 2008 & 2009 & 2010 & 2011 & 2012 & 2013 & 2014 & 2015 \\
\hline \hline Demand & 13.4 & 10.6 & 11.2 & 10.9 & 4.4 & -9.7 & 12.8 & 7.2 & 3.2 & 5.0 & 6.0 & 6.5 \\
\hline Supply & 8.0 & 10.5 & 13.6 & 11.7 & 10.9 & 5.2 & 8.3 & 6.8 & 4.9 & 5.0 & 5.0 & 6.0 \\
\hline
\end{tabular}

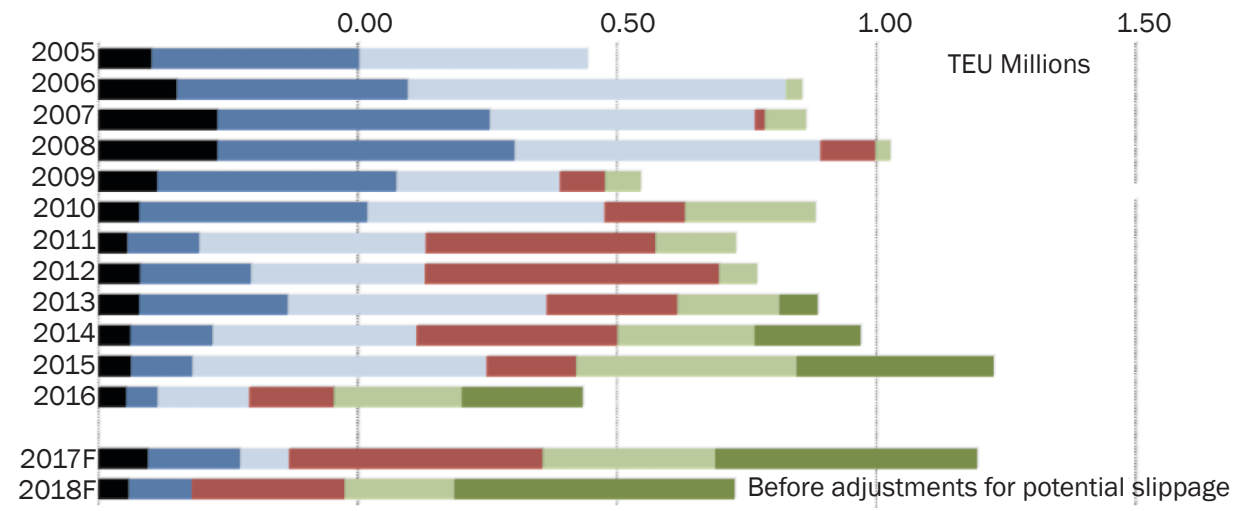

$<2,000$ TEU 2,000-5,100 TEU 5,100-10,000 TEU

10,000-13,300 TEU

13,300-18,000 TEU

$>18,000$ TEU

Figure 1 - New-building deliveries by year and by size from 2005 to 2016, with 2017 and 2018 forecast [4] 
- Charter rates reduction and charters cancellation,

- Freight rate wars,

- Job losses, and

- Debts, financial losses and bankruptcies and complete ceasing of the shipping activity.

Ships ordered prior to the 2008 crisis were due for delivery at its peak and for the couple of following years, increasing the complexity of the already fragile international market. The reduced trade has further created the overcapacity and brought cargo space demands to its minimums. Figure 1 shows the new-building deliveries by year and by size from 2005 to 2016, with 2017 and 2018 forecast;

The large number of Very and Ultra large ships (over 13,000 TEU) due to be delivered in 2017 and 2018, as shown in Figure 1 is expected to drive the containership fleet growth this and the next year. Some $78 \%$ of tonnage belongs to ships over 10,000 TEUs. The relatively high fleet growth rate for 2017 of over one million TEUs added, compared to 2016 when 0.93 million TEUs were delivered will prolong the overcapacity and further delay recovery on the container shipping market [4].
Due to overcapacity and reduced international production and trade, all the major trade routes have experienced a drop of the freight rates. Table 2 describes the freight rates on the major east - west trade route from 2009 to 2015;

The Far East - Europe is a major trade route mirroring the condition of container shipping. With such extreme drops and so low freight rates, as shown in Table 2, not only the profitability, but further exploitation of the vessel came into question. The ripple effects can be felt, even now with freight rates in average declining ever since 2009.

The other segment of container shipping industry Chartering, was deeply affected by the crisis. Large operators, in order to maintain the liquidity of the owned fleet had to drastically reduce the existing charter rates to third-party ships being employed on their major routes, either on Time or Voyage charters. In many instances, even completely cancelling the contracts. Fluctuation and decline of charter rates in the period 2000 - 2016 is presented in Figure 2;

Figure 2 shows that, after the constant growth since $1 Q$ of 2002, there was steep decline of charter rates in the $4 Q$ of 2008 with very little activities for

Table 2 - Freight markets 2009-2015 on the Far East - Europe Trade Route [1]

\begin{tabular}{||l|c|c|c|c|c|c|c|c||}
\hline \multicolumn{1}{|c|}{ Freight markets } & 2009 & 2010 & 2011 & 2012 & 2013 & 2014 & 2015 \\
\hline \multicolumn{1}{|c|}{ Far East - Europe } & \multicolumn{7}{c|}{ (Dollars per TEU) } \\
\hline \hline Shanghai - Northern Europe & 1,395 & 1,789 & 881 & 1,353 & 1,084 & 1,161 & 629 \\
\hline Percentage change & & 28.24 & -50.75 & 53.58 & -19.88 & 7.10 & -45.82 \\
\hline Shanghai - Mediterranean & 1,397 & 1,739 & 973 & 1,336 & 1,151 & 1,253 & 739 \\
\hline Percentage change & & 24.49 & -44.05 & 37.31 & -13.85 & 8.86 & -41.02 \\
\hline
\end{tabular}

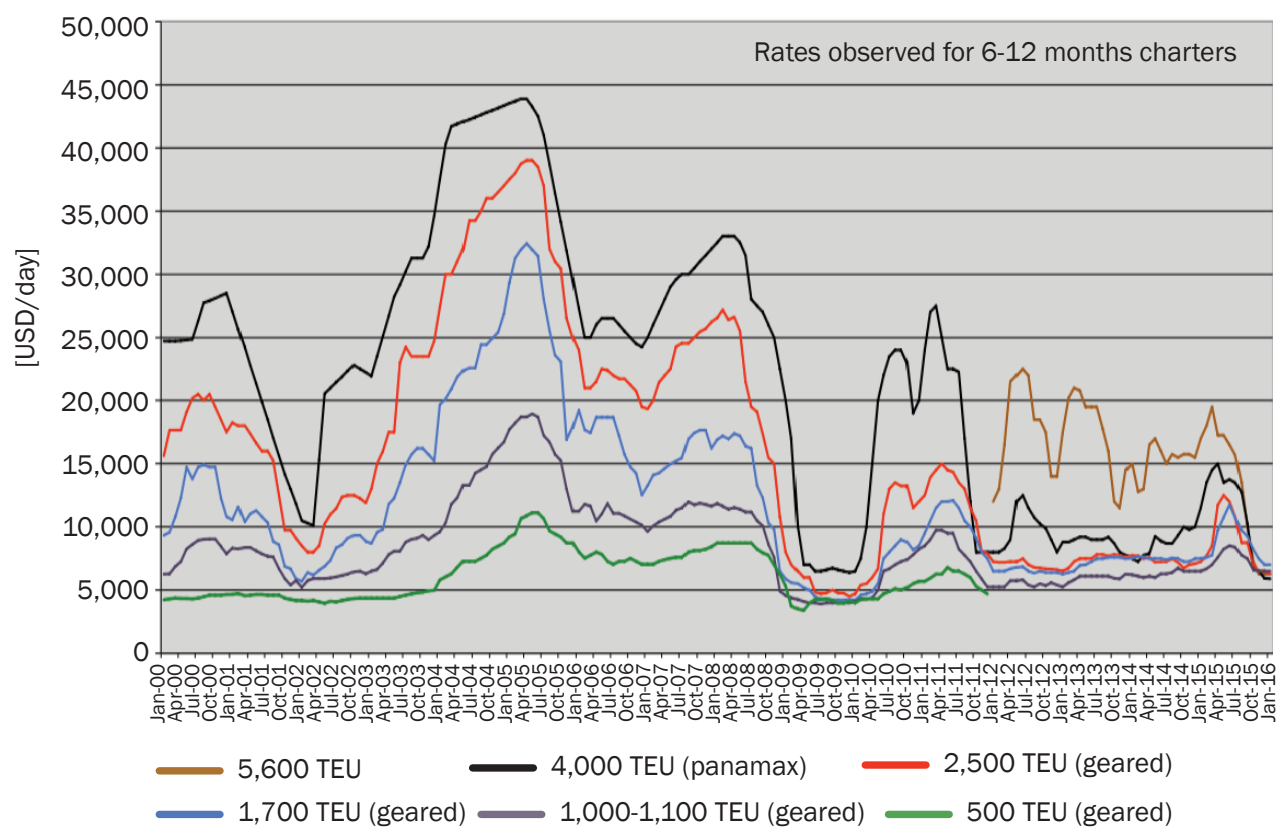

Figure 2 - Quarterly charter rates 2000-2016 [5] 
almost a year. At the end of 2009,572 ships with total capacity of 1,520,000 TEU had to be laid up. However, $70 \%$ of them were previously chartered vessels. It is definite that container shipping companies, specialized in chartering vessels to main operators, suffered the hardest. It is also clear from the graph that charter rates had never recovered the previous values ever since.

During the times of recession, the largest operators, with capital reserves, were able to offer their customers lower rates, even below liquidity, in order to remain on the market and push out the other, weaker operators. Such practices often led to so-called "freight wars" and that may further create additional debts, bankruptcies and in some cases complete ceasing of any shipping activity. By some estimations, during the crisis, complete container shipping has suffered a loss of 20 billion USD. Further low profit and credit insolvencies created at the end of 2009 a debt to commercial banks of up to 500 billion USD [6]. These, not restructured by banks or governments had to cease their shipping activities or file for bankruptcy.

Finally, as a result of laying up the vessels, expenses consolidation, bankruptcies, salaries reduction and laying up the personnel were common occurrences, which added the burden to national economies and delayed the recovery process.

\subsection{Aggravating circumstances}

Further to serious overcapacity, due to reduced demand for the container space, the following circumstances have aggravated the already difficult situation:

- Increased price of marine fuel,

- Self-imposed financial discipline, and

- Depreciation of USD value.

After the decades of low oil price (18-20 USD/ Barrel), beginning of $21^{\text {st }}$ century brings the steep increase of fuel prices, so that 2008 ends with USD 94.1 per barrel with rising trend until 2012 [7]. The price of fuel with crew cost is the major part of OPEX. Under the regime of low freight rates, any further expense reducing profitability, increasing the final price of transportation service eventually reduced even more the competitiveness of the operator on the market.

During the years of crisis, out of 500 billion USD of debt owned by container shipping companies, 40 international banks held $80 \%$ of total debt of which just the leading 12 banks held approximately $50 \%$ of the total debt. In order to protect the remaining assets and reserves, the major banks, involved in container shipping started to withdraw from the shipping market. Top ten banks reduced their loans in 2008 by half [6]. Such lack of financial investment has further deteriorated the situation on the container shipping market.
In the period from 2000 until 2008, USD has suffered a significant depreciation, particularly if compared to euro. The shipping market is traditionally connected to USD, since the freight and charter rates are formed and charged in that currency. Also, low dollar value has negatively affected the financial market, halting further investments [9].

\section{MEASURES AND STRATEGIES TO COPE WITH THE CRISIS}

Though last to feel the crisis within the shipping industry, container shipping was hit the hardest. The revenues for the main operators, for the first quarter of 2009 plunged by $35 \%$, when compared to the same period in 2008 or estimated 45 billion USD [10]. The immediate and radical actions had to be taken for the sake of survival. Most traditional first aid measure in the times of financial difficulties is the reduction in capacity.

\subsection{Capacity consolidation}

The world container fleet capacity grew by $103 \%$ from 2000 to 2007 (5,150,000 - 10,467,000 TEU) [11]. With the tonnage ordered before 2008 and due for delivery, urgent reorganization of capacity was necessary to remain in business. Due to its nature new-building contracts cancellation or delays are very expensive and subject to high penalties as well as long negotiations. Therefore, the measures with immediate effect were the most traditional ones:

- Lay-ups,

- Selling and scrapping,

- Reducing the sailing speed, and

- Blank sailing

Laying up the vessels in the time of crisis is a wellknown and time-proven consolidation measure. By estimates, during 2009 there was a lay-up of $10-15 \%$ of container tonnage. Total laid up capacity reached 1,400,000 TEU [1].

Additionally, due to the existing overcapacity, the secondhand ships market almost came to a halt because of very low demand. Before the crisis, the usual age of ships sent to the scrapyard was over 40 years. During 2009 the scrapped container capacity was 364,300 TEU, compared to 2008's 99,900 TEU. However, the average age of the ships sent for demolition was 27 years only. Even such an extreme measure resulted in total reduction of fleet capacity by 3\% [1].

The speed of a vessel has a dramatic impact on the fuel consumption because the speed is related to the propulsive power required by approximately a third or fourth power relationship. Likewise, sailing at 90 percent of the design speed requires only 75 percent of the power. The corresponding reduction in total fuel consumption is offset a bit by the longer time 
spent to complete the voyage. So, by slowing down by 10 percent the vessel can save about 20 percent in fuel for a given voyage. This significant savings make it easy to understand why so-called "Slow Steaming", a relatively new strategy, compared to the above two traditional measures was developed. Besides directly reducing the fuel expenses, this measure creates artificially tonnage demand by simply prolonging the sea voyage time. With traditional weekly port calls on respective service lines, the prolongation of sea voyage from four to six weeks, opens an opportunity to add additional two ships, hence reducing present overcapacity. Together with the implicated freight raise, due to increased transportation space demand it is also an environmental friendly measure since less consumption means less air polluting emissions [8].

Blank sailing is also a new measure, when one of the ships on a given line is halted for the duration of one week or more. Such practice artificially generates demand for the container capacity and results in higher freights.

\subsection{Optimization and operating expenses reduction}

Together with capacity consolidation, OPEX optimization and reduction of day-to-day operating costs is another traditional immediate measure with immediate effect. The main operational expenses are:

- Fuel and lubricants,

- Crew expenses,

- Maintenance, spares, consumables, etc.

Fuel and lubricants represent on average 55\% of OPEX. Together with Slow Steaming, high attention was given to development of energy efficiency procedures and their application, as well as to personnel training.

An immediate measure, with prompt results, is the reduction of the number of crew on board the vessel to minimum allowed by Class and Flag authorities. Though shipping operators were fully aware that such measures, during the long-term reduce the level of service quality, the severity of the crisis presented such a measure as an acceptable risk.

For the duration of crisis, in most cases the level of maintenance was reduced to bare minimum to keep the vessels safe and seaworthy. The same applies to the supply of spare parts and consumables.

Complete shipping industry has undertaken strict measures to control OPEX, but container shipping, being hit the worst, had the best results, as shown in Figure 3.

Besides very strict OPEX control, the varieties of organizational and business optimization measures were undertaken. Those measures were better line and route planning, return to core business and cease of horizontal integration processes, as well as reduction and laying down of shore employees. The results

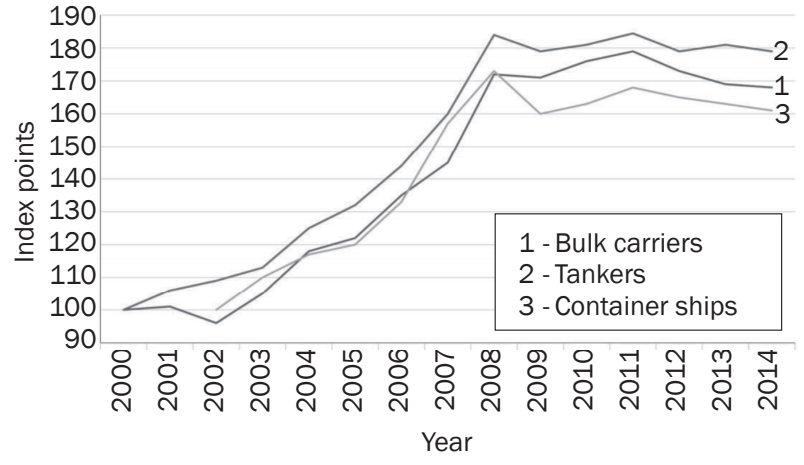

Figure 3 - Trends of operating costs indices from 2000 to 2014 [10]

were instant and as shown in Figure 3, with immediate reduction of operational expenses upon the onset of 2008 crisis has stopped the continuous growth that characterized the previous decade and held them at almost the same level since then.

\subsection{Economy of scale}

The capacity consolidation measures have removed from the marked obsolete and energy-inefficient ships. At the same time, shipyards started to deliver modern, efficient vessels of large capacity (up to $18,000 \mathrm{TEU})$, operated by smaller crew and creating the condition to reap the benefits of the economy of scale laws in container shipping.

Economy of scale and scope are not something new to container shipping industry. However, due to the lack of financial support, the activities related to economy of scope (vertical and horizontal integration, fleet diversification, etc.) had to be reduced to minimum or to completely cease. The benefits of the economy of scale were realized through two levels of activities and were quickly seized by opportunistic managements.

On the production level, the answer was to increase the vessel size, so the first decade of $21^{\text {st }}$ century brought on the market vessels reaching over 20,000 TEU [12].

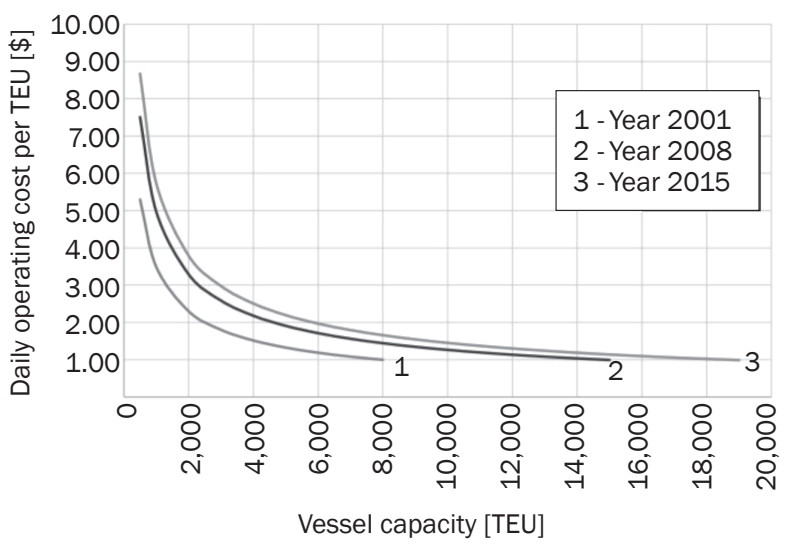

Figure 4 - Daily operating cost per TEU [12] 
Figure 4 indicates the reduction of operating costs by increasing the ship's size. The difference between daily expenses among different classes of container ships grow much slower than their capacity rate. For example, fuel consumption per day of 6,000 TEU ships, under the slow steaming regime is around 60 tons and for 18,000 around 120 tons while later vessels carry three times more cargo [13]. The number of crew is almost the same, as well as the maintenance cost. Therefore, as shown in Graph 4, the cost for 18,000 TEU vessels are half the cost of those of 6,000 TEU.

\subsection{Integrations - conferences, alliances, mergers and acquisition}

On the company level, the solution was the creation of liner conferences, global strategic alliances (GSA) and mergers and acquisitions (M\&A). For more of a century, the liner conferences were the way for the shipping companies to control the tariffs on certain routes, while keeping exclusive control of their own operations. However, the last decade has brought creation of global trade strategic alliances. The operators share the resources, assets, information and part of the operational control in order to increase the scope and volume of the business on global container market. Such alliance enables great reduction of operating costs, controlling the risks, improving the reliability and efficiency of service, increasing the presence in port of calls and generally offering the higher level of service to customers [11B]. Today, most of the operators are grouped into GSAs. Major GSAs are 2M (APM Maersk Line and Mediterranean Shipping Co.), Ocean Alliance (CMA CGM Group, COSCO; UASC; Evergreen Line) and G6 (OOCL, Happag-Lloyd, MOL, NYK Line, Hyundai M.M.). However, it is almost certain that alliances will get reshuffled in the near future [14].

Though not a new strategy, the last decade has brought a series of mergers and acquisitions (M\&A) in container shipping market. The market itself is very competitive and all operators, particularly the major ones, tend to increase their assets in order to reach the critical capacity mass to reduce the operating expenses, obtain larger degree of market flexibility and finally remove the competitors and create favourable freight rates for themselves [16]. Today, top $15 \mathrm{com}$ panies in container shipping are as shown in Table 3.

\section{FORECASTS AND EXPECTATIONS FOR THE FUTURE}

In order to cope with the crisis and adapt to the new business environment, container shipping had to change. Those who had better reserves or any access to financial markets succeeded in consolidating their operations by utilizing new technological or organizational assets and placed themselves into better competitive position. The importance of proper analysis of market situation and operational planning is of utmost importance since even at the end of 2016 idle capacity was 1,419,649 TEU [17]. Carefully observing and analysing the market fluctuation, it is possible to isolate below the key factors that will shape the demand trends on the container shipping market [18]:

- Insufficient demand for container capacity,

- Overcapacity,

- Record low prices of marine fuel,

- Global fluctuation of the market,

- Emerging markets,

- Limitation for further growth of containerization processes,

- Increased capacity and improved technology of container terminals,

- Sustainable development and environment awareness, and

- New technologies, operational transparency and customer support.

Despite the fact that in the last two years the world GDP has steadily risen by $2.5 \%$, it was eventually below estimations. However, it is still an indication of slow recovery. At the same time, Chinese economic growth has slowed down and with China being the major generator of seaborne transportation on all the major trade routes, the result was a steady reduction of demand and insufficient utilization of the world fleet's 20,265,925 TEU, as tallied on 31st December 2016 [17].

Table 3 - Top 15 container operators as of 27th January 2017 [15]

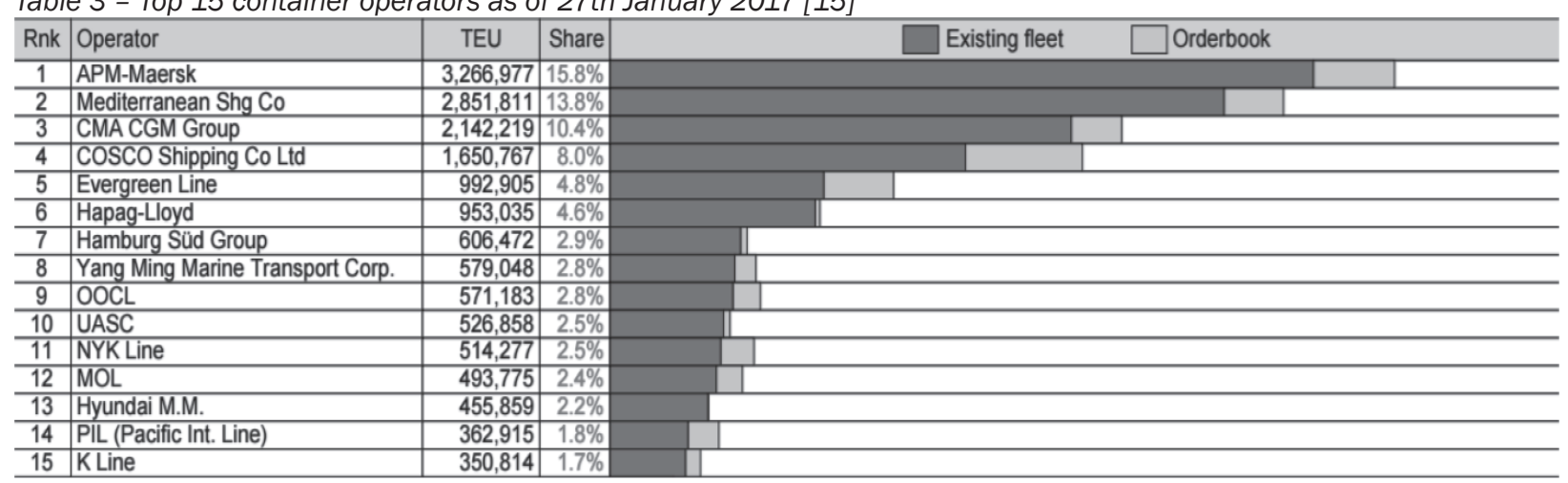


From the very onset of crisis, overcapacity is the major problem of the container shipping market. The imbalance between demand and supply, due to lower demand and steady delivery of the new tonnage is estimated to remain until 2019. Only in 2016, there were 136 ships with capacity of 934,460 TEU delivered to the operators. The order book as of 31st December 2016 was 413 ships with total capacity of 3,187,665 TEU [17].

Ever since 2013, the trend of the declining price of crude oil (USD 40.68 per barrel for 2016) was a palpable treat to delicate balance of the container market [7]. Some operators, in order to improve the service decided to seize the opportunity and increase the voyage speed, hence causing additional overcapacity and drop of the freight rates.

Political instability, wars, embargoes, etc. seriously influence trade flows by creating the fluctuations of the world market. Recent unrests in the Middle East, war in Ukraine and trade embargo on Russia, significantly reduced the cargo traffic, particularly on the North European and Baltic routes.

In the meantime the new regions with significant demographic and industrial growth, for example Nigeria, with the present population of 174 mill and the expected in 2050 of 440 million, open the possibilities for potential growth of container industry.

In addition, the process of commodities containerization has reached its plateau. There are seldom any commodities not being presently transported in containers. The main reasons were security, reliability, cost efficiency and flexibility of transport. Today, for example, modern mega post-panamax vessel (> 14,000 TEU) can carry more refrigerated cargo than conventional specialized reefer vessels, pushing those vessels out of the market.

Due to the low operational intensity during the crisis, many container terminal operators used this time for modernization and expansion of their terminals, preparing them for larger vessels of the latest design as well as the estimated increase of trade volume. Such surplus of cargo handling facilities increased the competition between terminals and placed the liners in a position to carefully study the benefits of choosing the exact terminal for their routes. It must be said that large operators, often within the process of vertical integration tend to take control of the key positioned terminal to secure uninterrupted cargo flow and ship schedules.

The recent years have brought a shift in the environment protection awareness among the major line operators and shipping companies. Energy efficiency, use of renewable sources of energy, increased training of the ship and shore personnel, improvement in ships and engine designs, reduction of air pollution by exhaust gases, use of biodegradable and bio friendly materials in building containers, as well as strict adherence to positive international, national and classification regulations changed the face of modern container shipping making it another link in the logistic chain, based upon the policy of sustainable development [19].

Within the supply chain, all subjects from the manufacturer to the end user are highly motivated toward investments in the new technologies in order to increase the efficiency and productivity. The development of communications and IT platforms enabled better transparency for establishing cooperation and developing higher level of service to the end user [20].

A myriad of factors are necessary to maintain the balance between demand and supply on the container shipping market, while at the same time keeping the profitability. In order to remain competitive and successful on the international market, proper and timely analysis of all the above factors, as well as further consolidation of cargo capacity, reduction of operational expenses, flexible and innovative line structure and vessel deployment, responsible and transparent freight rates, diversity and open-minded service palette, as well as wisely developed adaptive strategy are factors and activities to be carefully considered at all times.

\section{CONCLUSION}

Global economic crisis commenced in 2008 had the most serious impact among the container carriers and shock waves are still felt on the shipping market. A combination of low demand and steady delivery of newly ordered, large and modern ships, created overcapacity. Freight, charter, ship scrappers and secondhand market rates dropped below the profitability limit and all the companies experienced the difficulties to a larger or lesser extent. However, none was spared.

Throughout this paper the order of events has been presented that led to the above-mentioned crisis and the major shift of the strategies undertaken by the leading container shipping companies in order to cope with hostile business environment. Mostly, those activities were concentrated in consolidation and cost control activities within the companies and toward the outside, large movements toward the mergers and takeovers in order to gain stronger positions on the market and establish the domination by the sheer force of capacity and service volume.

However, the following years will bring more consolidation, but not at the speed seen previously. There are still a number of attractive medium-sized carriers that have been left behind during the recent $M \& A$ and some may decide that catching up is too costly or unprofitable in the medium term and decide to sell up to larger carriers. On the other side, the pool of potential buyers with sufficient financial resources is quite limited. Particularly, banks are less able and inclined to 
lend money and the borrowing costs are rising due to new regulations and self-imposed limitations. However, despite the stringiest measurements, the forecasts warn that overcapacity will persist, despite reluctant investor's climate at least until the year 2019.

Despite the grave consequences, there were also positive effects. Fleet capacity optimization, improvement of operation efficiency, cost control and cost reduction, strengthening of information exchange, advances in environmental protection and sustainable development, debt restructuring, creation of global alliances, mergers and acquisitions and exploration of economy of scale have produced positive effects, thus enabling the prudent carriers to remain on container shipping market. Those are also the paths, most recommended for further research. Particularly the cost optimization techniques, digital transformation of shipping business and sustainable and renewable energy sources are the avenues that are most promising for the future.

VLADIMIR JEREBIĆ, dipl. ing. pomorskog prometa ${ }^{1}$ E-mail: vladimir.jerebic1@optinet.hr

STANISLAV PAVLIN, Ph.D. ${ }^{1}$

E-mail: stanislav.pavlin@fpz.hr

${ }^{1}$ Sveučilište u Zagrebu, Fakultet prometnih znanosti

Vukelićeva 4, 10000 Zagreb, Croatia

\section{GLOBALNA EKONOMSKA KRIZA I OPERATIVNA STRATEGIJA KONTEJNERSKIH PRIJEVOZNIKA}

\section{SAŽETAK}

Brodarsko tržište je ekonomska izvedenica proizvodnog i robnog tržišta i prema tome ovisno o cikličkim promjenama kao što su depresija i konjunktura. Rad analizira stanje na globalnom tržištu prijevoza kontejnera uzrokovano dugotrajnom ekonomskom i financijskom krizom, započetom 2008. godine koja je još uvijek uočljiva unutar kontejnerskog brodarstva i zrcali se prekomjernom tonažom i niskim vozarinama. Članak se bavi strateškim promjenama poslovanja pomorskih kontejnerskih prijevoznika, te osmišljavanjem i primjenom unaprijeđenih prometno-tehničkih, ekonomskih, organizacijskih i komercijalnih mjera s ciljem prilagodbe novo nastalim uvjetima poslovanja. Konačno, prikazuju se prognoze razvoja tržišta, te mogući problemi i mjere njihovog rješavanja.

\section{KLUČNE RIJEČI}

kontejnersko brodarstvo; utjecaj ekonomske krize; promjene poslovne strategije; konsolidacija; prognoza tržišta;

\section{REFERENCES}

[1] Review of Maritime Transport. UNCTAD, UN, New York, USA; 2017.

[2] Haralambides HE, Thanopoulu H. The Economic Crisis of 2008 and World Shipping: Unheeded Warnings. SPOUDAI Journal of Economics and Business. May 2014;64(2): 5-13. Available from: https://econpapers. repec.org/article/spdjournl/v_3a64_3ay_3a2014_3ai _3a2_3ap_3a5-13.htm [Accessed on February 2017].

[3] Samaras I, Papadopoulou EM. The Global Financial Crisis - The Effects on the Liner Shipping Industry and the Newly Adopted Leading Practices. Paper presented at: $1^{\text {st }}$ Olympus International Conference on Supply Chains (ICSC 2010), 1-2 Oct 2010, Katerini, Greece. Available from: http://www.teicm.gr [Accessed on February 2017].

[4] Alphaliner Weekly Newsletter. Volume 27, Issue 04, January 2017. Available from: http://www.alphaliner. com/ [Accessed on February 2017].

[5] Alphaliner Portal. Available from: http://www.alphaliner. com/liner2/research_files/liner_studies/nograph/Alphaliner-CharterRates.pdf [Accessed on February 2017].

[6] World Bank Global Economic Prospects 2010. Washington DC, USA: The World Bank Publication; 2010.

[7] Statista, The Statistical Portal. Available from: https:// www.statista.com/statistics/262858/change-inopec-crude-oil-prices-since-1960/ [Accessed on February 2017].

[8] Bomboma K, Tshibuyi MC. The Financial and Economic Crisis, Its Impacts on the Shipping Industry, Lessons to Learn: The Container Market Analysis. Open Journal of Social Sciences. 2016;4(1): 38-44.

[9] Macro trends, The Statistical Financial Portal. Available from: http://www.macrotrends.net/1329/us-dollar-index-historical-chart [Accessed on February 2017].

[10] The Financial and Economic crisis of 2008 - 2009 and Developing Countries. UNCTAD, UN, New York, USA, Genève, Switzerland; December 2010.

[11] Greiner R, Moore Stephens LLP. Ship Operating Cost: Current and Future Trends. Available from: https://www. opcostonline.com/\#/ [Accessed on February 2017].

[12] Murray W. Economies of Scale in Container Ships Costs. North America's Premier International Shipping Conference, March 2016, Stamford, Connecticut, USA.

[13] Notteboom T, Carriou P. Fuel surcharge practices of container shipping lines: Is it about cost recovery or revenue making. Proceedings of the 2009 International Association of Maritime Economists (IAME) Conference, June 2009, Copenhagen, Denmark.

[14] Panayides PM, Wiedmer R. Strategic Alliances in Container Liner Shipping. Research in Transportation Economics. Aug 2011;32: 25-38.

[15] Alphaliner Portal, Top 100. Available from: http:// www.alphaliner.com [Accessed on February 2017].

[16] Alexandrou G, Gounopoulos D, Hardy MT. Mergers and Acquisitions in Shipping. Transportation Research Part E. Jan 2014;61: 212-234.

[17] Alphaliner Weekly Newsletter. Volume 2017, Issue 01, January 2017. Available from: http://www.alphaliner. com/ [Accessed on February 2017].

[18] Damas P. 2016 Container Shipping outlook: Assessing the Fundamentals. TPM Conference, February/March 2016, Long Beach, Ca. USA. Available from: http:// www.ciffa.com/wp-content/uploads/2016/03/Day1-Presentation-4c-Philip-Damas-DREWRY_Container-Shipping-Outlook.pdf [Accessed on February 2017].

[19] Rex C. Shipping Market Review. Copenhagen, Denmark: Danish Ship Finance; May 2017.

[20] DNV. Shipping 2020. Hovik, Norway: Det Norske Veritas; Aug. 2012. 